\title{
Infection of bovine well-differentiated airway epithelial cells by Pasteurella multocida: actions and counteractions in the bacteria-host interactions
}

\author{
Ang Su ${ }^{1 \dagger}$, Jie Tong ${ }^{4 \dagger}$, Yuguang $\mathrm{Fu}^{3}$, Sandy Müller ${ }^{2}$, Yenehiwot Berhanu Weldearegay ${ }^{2}$, Paul Becher ${ }^{1}$,
} Peter Valentin-Weigand ${ }^{2}$, Jochen Meens ${ }^{2^{*}}$ and Georg Herrler ${ }^{1^{*}}$ (i)

\begin{abstract}
Pasteurella (P.) multocida is a zoonotic pathogen, which is able to cause respiratory disorder in different hosts. In cattle, P. multocida is an important microorganism involved in the bovine respiratory disease complex (BRDC) with a huge economic impact. We applied air-liquid interface (ALI) cultures of well-differentiated bovine airway epithelial cells to analyze the interaction of $P$. multocida with its host target cells. The bacterial pathogen grew readily on the ALI cultures. Infection resulted in a substantial loss of ciliated cells. Nevertheless, the epithelial cell layer maintained its barrier function as indicated by the transepithelial electrical resistance and the inability of dextran to get from the apical to the basolateral compartment via the paracellular route. Analysis by confocal immunofluorescence microscopy confirmed the intactness of the epithelial cell layer though it was not as thick as the uninfected control cells. Finally, we chose the bacterial neuraminidase to show that our infection model is a sustainable tool to analyze virulence factors of P. multocida. Furthermore, we provide an explanation, why this microorganism usually is a commensal and becomes pathogenic only in combination with other factors such as co-infecting microorganisms.
\end{abstract}

Keywords: Pasteurella multocida, air-liquid interface (ALI) cultures, bacterial pathogenesis, host-pathogen interactions

\section{Introduction}

Bovine respiratory disease is a multifactorial disease complex of cattle (BRDC) [1-3]. Pasteurella multocida is one of the most important bacterial pathogens related to BRDC [3-5]. With its broad host range comprising humans, domestic animals and wild animals $[1,6,7]$,

\footnotetext{
*Correspondence: Jochen.Meens@tiho-hannover.de; Georg. Herrler@tiho-hannover.de

${ }^{\dagger}$ Ang Su and Jie Tong contributed equally to this work

${ }^{1}$ Institute of Virology, University of Veterinary Medicine Hannover, Foundation, 30559 Hannover, Germany

2 Institute of Microbiology, University of Veterinary Medicine Hannover, Foundation, 30559 Hannover, Germany

Full list of author information is available at the end of the article
}

P. multocida is considered as one of the most prevalent commensals and opportunistic pathogens worldwide $[7,8]$. As a commensal of cattle, P. multocida is located in the upper respiratory tract $[1,9-11]$; the pathogenesis of the respiratory disease and the interactions with other respiratory pathogens are largely unknown. Several bacterial components have been identified as virulence factors, e.g. the capsule, lipopolysaccharides, and the neuraminidase (sialidase) [8,12-17]. A neuraminidase is found in most $P$. multocida strains $[14,18]$. By releasing sialic acid from glycosylated host proteins and lipids, the enzyme provides a carbon source for bacterial amplification $[19,20]$; furthermore, it may help to escape the host defense mechanisms by releasing sialic acid from mucins

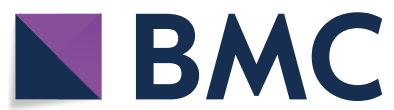

(c) The Author(s) 2020. This article is licensed under a Creative Commons Attribution 4.0 International License, which permits use, sharing, adaptation, distribution and reproduction in any medium or format, as long as you give appropriate credit to the original author(s) and the source, provide a link to the Creative Commons licence, and indicate if changes were made. The images or other third party material in this article are included in the article's Creative Commons licence, unless indicated otherwise in a credit line to the material. If material is not included in the article's Creative Commons licence and your intended use is not permitted by statutory regulation or exceeds the permitted use, you will need to obtain permission directly from the copyright holder. To view a copy of this licence, visit http://creativeco mmons.org/licenses/by/4.0/. The Creative Commons Public Domain Dedication waiver (http://creativecommons.org/publicdomain/ zero/1.0/) applies to the data made available in this article, unless otherwise stated in a credit line to the data. 
[21], a crucial component of the ciliary clearance function $[22,23]$.

The airways are lined by a layer of epithelial cells that form a primary barrier to invading respiratory pathogens. Mucins released by mucus-producing cells can entrap detrimental substances including microorganisms [24, 25], which are then transported out of the respiratory tract by the coordinated movement of the cilia present on ciliated cells [24, 26]. Another crucial component of the airway epithelium is the basal cells, which ensure the regeneration capacity when part of the cells have been lost, e.g. by damage due to environmental material [27]. To maintain the barrier function, the epithelial cells have a polarized organization. A characteristic feature of the cellular polarity is that the plasma membrane is divided into an apical domain facing the environmental side of the epithelium and a basolateral domain facing the internal milieu. The two domains have a different composition and are separated by tight junctions that not only prevent an intermixing of the components of the two membrane domains but also form a tight connection to the neighboring cells, which prevent an invasion of pathogens via the paracellular route [24]. For many microorganisms, the role of the respiratory epithelium during infection remains largely unknown. As a close in vitro representation of the airway epithelium, air-liquid interface (ALI) cultures of well-differentiated epithelial cells have been utilized to analyze infection by different pathogens including viruses and bacteria [27-31].

We have applied filter-grown cultures of bovine welldifferentiated airway epithelial cells to analyze the bacterial infection. P. multocida grew readily on the bronchial epithelial cells cultures and induced a substantial loss of ciliated cells. Despite this loss, the epithelial cell layer maintained the barrier function as indicated by the transepithelial electrical resistance (TEER). This was achieved by a reorganization process that resulted in a reduced thickness of the epithelial cell layer. Furthermore, we present evidence that the bovine ALI cultures can be used to analyze the role of the bacterial neuraminidase as a virulence factor.

\section{Materials and methods}

\section{Differentiated bovine airway epithelial cell cultures}

Fresh lungs were collected from calves slaughtered at a local slaughterhouse in Germany. Bovine primary bronchial epithelial cells (PBEC) were isolated as previously described [30] and were expanded in growth medium (BEGM). When the PBEC reached confluence, the cells were transferred to Transwell ${ }^{\circledR}$ polycarbonate membranes (Corning) and maintained under the air-liquid interface (ALI) conditions for at least 4 weeks at $37{ }^{\circ} \mathrm{C}$ in a humidified $5 \% \mathrm{CO}_{2}$ atmosphere. During this time, the cells grew to a pseudostratified monolayer; as the nuclei were located at different heights, the cells appeared to have a multilayered organization. While all differentiated cells have contact to the filter substrate, there are several basal cells interspersed at the bottom of the monolayer [32].

\section{Bacterial strain and growth conditions}

The applied bacterial strain in this study was $P$. multocida strain 1701. P. multocida 1701 is a field strain, isolated from purulent nasal exudate of dairy cattle [33]. The strain belongs to the capsular serogroup $\mathrm{A}$, which is the most prominent type in bovine [34, 35]. For the profiling of virulence associated genes, we used a multiplex PCR assay [33, 36, 37], and two additional single gene PCR's for $h g b B$ and $t b p A$ [34]. The results indicated, that the strain harbors most of the tested genes, including the two sialidase encoding genes $n a n H$ and $n a n B$, but not the dermonecrotic toxin gene tox $A$ (Table 1). Based on published methods [38], the recovered cryo-stocks bacteria were used for the infection experiment. Bacteria were recovered from cryo-stocks according to the following protocol. Cryo-conserved $P$. multocida were grown on Columbia agar supplemented with $7 \%$ sheep blood (Oxoid) overnight under aerobic conditions at $37^{\circ} \mathrm{C}$. One colony of $P$. multocida from a blood agar plate was inoculated into BHI broth and incubated overnight at $37{ }^{\circ} \mathrm{C}$ with shaking. Afterwards, $20 \mathrm{~mL}$ fresh BHI medium was inoculated with the overnight broth culture to an initial $\mathrm{OD}_{600}$ of 0.05 . This was allowed to grow for $4-5 \mathrm{~h}$ until it reached an $\mathrm{OD}_{600}$ of approx. $2.5 \pm 0.3$, which was found

\section{Table 1 Virulence associated genes and capsule types detected in P. multocida strain 1701}

\begin{tabular}{llll}
\hline Process or enzyme & Gene & Gene test & Reference \\
\hline Capsule biosynthesis (CapA) & hyaD-hyaC & + & {$[37]$} \\
Dermonecrotic toxin & toxA & - & {$[36]$} \\
Outer membrane protein & omA87 & + & {$[36]$} \\
& ompH & - & {$[36]$} \\
& ompA & - & {$[36]$} \\
Sialidases & plpB & + & {$[36]$} \\
& nanH & + & {$[36]$} \\
Adhesins & nanB & + & {$[36]$} \\
& ptfA & + & {$[36]$} \\
Iron metabolism & pfhA & + & {$[36]$} \\
& tonB & + & {$[36]$} \\
& hgbA & + & {$[36]$} \\
& hgbB & - & {$[34]$} \\
& tbpA & + & {$[34]$} \\
\hline
\end{tabular}

In 'Gene test' column, ' + 'represent to positive for the gene test and ' - ' to negative. 
to be the mid of the logarithmic growth phase. The number of bacteria was determined by plating serial tenfold dilutions on Columbia agar plates supplemented with $7 \%$ sheep blood. Bacterial titers are presented as CFU per milliliter $(\mathrm{CFU} / \mathrm{mL})$.

\section{Bacterial infection of well-differentiated epithelial cells} Well-differentiated PBECs were kept in the absence of antibiotics and antimycotics $24 \mathrm{~h}$ prior to bacterial infection. The cell number per filter support was approximately $5 \times 10^{5}$. Transwell filters were washed five times with warm PBS and infected with $P$. multocida inoculum in $100 \mu \mathrm{L}$ final volume added to the apical surface at three different conditions: $10^{2} \mathrm{CFU}$ for $1 \mathrm{~h}, 10^{2} \mathrm{CFU}$ for $4 \mathrm{~h}, 10^{5} \mathrm{CFU}$ for $4 \mathrm{~h}$. Control cells were mock-infected with PBS. After the inoculation period, PBEC were rinsed with warm PBS twice to remove unbound bacteria and fresh ALI medium without antibiotics and antimycotics was added only at the basolateral compartment. Infected PBEC were incubated for up to $24 \mathrm{~h}$ under ALI conditions at $37{ }^{\circ} \mathrm{C}$ and $5 \% \mathrm{CO}_{2}$. As there was no medium present in the apical compartment, bacteria could grow only on nutrients derived from the mucus-covered epithelial cell layer, similar to natural infections. At 4, 12, and 24 hpi, $100 \mu \mathrm{L}$ of ALI medium were applied apically and the cultures were incubated for $30 \mathrm{~min}$ at $37{ }^{\circ} \mathrm{C}$. After removal of the supernatant, cells were kept again under ALI conditions until the next time point of sample collection. Replicate plating of supernatants was performed with tenfold serial dilutions on Columbia agar supplemented with 7\% sheep blood to determine the bacterial growth kinetics.

\section{Measurement of the barrier integrity}

Respiratory epithelial cells were grown under ALI conditions. The transepithelial electrical resistance (TEER) was determined by using the Millicell ${ }^{\circledR}$ ERS-2 Voltohmmeter (Millipore) according to the manufacturer's instructions.

To determine the permeability for macromolecules, FITC-labelled dextran $(70 \mathrm{kDa})$ (Invitrogen) was applied to the apical compartment. Medium was collected from the basolateral compartment at different time points, and analysed for fluorescence with a spectrophotometer (Varian Cary Eclipse).

\section{Cytotoxicity assay}

Filter-grown cultures of well-differentiated airway epithelial cells were used to determine the cytotoxic of effect of the bacterial infection. For the determination of the cytotoxicity effect, $70 \mu \mathrm{L}$ PBS were added to the apical compartment and cells were incubated on a horizontal shaker for $5 \mathrm{~min}$. Supernatants were collected at different time points and analyzed for the release of LDH by using the Cytotx ${ }^{\circledR} 96$ assay kit (Promega). All the experiments were performed at least three times.

\section{Analysis of the importance of the neuraminidase}

To analyze the importance of the neuraminidase of $P$. multicida, cells were either pretreated with exogenous neuraminidase or incubated in the presence of a neuraminidase inhibitor. Bovine epithelial cells were treated with neuraminidase from $C$. perfringens (Sigma-Aldrich) at $200 \mathrm{mU}$ for $1 \mathrm{~h}$ at $37^{\circ} \mathrm{C}$ prior to bacterial infection. After removal of the enzyme by washing three times, $100 \mathrm{CFU}$ of bacteria in $100 \mu \mathrm{L}$ medium were applied. After $1 \mathrm{~h}$, the infection was continued as described above. For the inhibition experiment, the neuraminidase inhibitor (NAI) DANA (Sigma-Aldrich) was added at a final concentration of $1 \mathrm{mM}$ to the inoculum and to the maintenance ALI medium up to $24 \mathrm{hpi}$. Supernatants were collected at 4, 12, 24 hpi to determine the cytotoxicity, the bacterial growth kinetics and for immunofluorescence microscopy.

\section{Immunofluorescence microscopy}

All infected and mock-infected samples were washed with PBS three times and fixed with 3\% paraformaldehyde (PFA) for $20 \mathrm{~min}$. PFA was removed and $0.1 \mathrm{M}$ glycine was added for $5 \mathrm{~min}$. Samples were permeabilized with $0.2 \%$ Triton $\mathrm{X}-100$, washed three times with PBS and were further blocked with $5 \%$ goat serum and incubated with a primary and a secondary antibodies consecutively for $1 \mathrm{~h}$ each. After washing with PBS, the nuclei were stained with DAPI (4',6-diamidino-2-phenylindole) and embedded in Prolong Gold Antifade Reagent (Life Technologies), and stored at $4{ }^{\circ} \mathrm{C}$ for further analysis.

$P$. multocida infected samples and control samples were stained with Cy3-labeled antibody against $\beta$-tubulin (1:300, Sigma) as primary antibodies. Samples were analyzed by using an inverse microscope Nikon Eclipse Ti-S (Nikon) and TCS SP5 confocal laser scanning microscope (Leica). Images were analyzed using NIS-Elements Viewer 4.20 software (Nikon), while imaging analysis of cilia coverage rates to the well-differentiated cells was calculated by using ImageJ.

\section{Statistical analyses}

All in vitro experiments were performed at least three times and data were analyzed using GraphPad Prism (GraphPad Software version 8, San Diego, CA, USA) software with Tukey multiple comparison test. Results were shown as means with standard deviations. A p-value of $<0.05$ was considered significant. 


\section{Results}

\section{Growth kinetics of $P$. multocida on differentiated bovine} airway epithelial cells

To determine the growth kinetics of Pasterella multocida on differentiated airway epithelial cells, filter-grown bovine ALI cultures were infected by strain 1701 (for virulence profile see Table 1 and Materials and Methods) from the apical side. Supernatants were collected at 4, 12 and $24 \mathrm{~h}$ post-infection and used to determine the colony forming units (CFU). Between the time points of sample collection, the cells were maintained under air-liquid interface conditions. As shown in Figure 1, P. multocida grew readily under the ALI culture conditions. Bacterial replication was dependent on the number of CFU applied in the inoculum and on the inoculation time. The sample with the most favorable conditions $\left(10^{5} \mathrm{CFU}, 4 \mathrm{~h}\right)$ grew to a concentration of $10^{6} \mathrm{CFU} / \mathrm{mL}$ by $4 \mathrm{~h}$ post infection (hpi); to reach the same concentration, it took more than $12 \mathrm{~h}$ for the second group $\left(10^{2} \mathrm{CFU}, 4 \mathrm{~h}\right)$ and more than $24 \mathrm{~h}$ for the third group $\left(10^{2} \mathrm{CFU}, 1 \mathrm{~h}\right)$ (Figure 1$)$. It should be noted that in this experimental setup, bacteria were kept in the absence of media in the apical compartment. Therefore, bacterial growth was dependent on nutrients derived from the mucus-covered epithelial cell layer.

\section{Detrimental effect induced by $P$. multocida infection}

Having shown that $P$. multocida is able to grow on differentiated airway epithelial cells, it was interesting to learn whether the bacterial infection has a detrimental effect on the respiratory epithelial cells. For this purpose, we analyzed the cytotoxic effect of $P$. multocida. Differentiated bovine airway epithelial cells were infected by $100 \mu \mathrm{L}$ of strain 1701 from the apical side using the same inoculation conditions as described above for the growth curve $\left(10^{5} \mathrm{CFU}, 4 \mathrm{~h} ; 10^{2} \mathrm{CFU}, 4 \mathrm{~h} ; 10^{2} \mathrm{CFU}, 1 \mathrm{~h}\right)$. To get information about the cytotoxicity, we determined the amount of lactate dehydrogenase $(\mathrm{LDH})$ released into the supernatant. As shown in Figure 2, in the supernatants of cells infected by $P$. multocida an increased amount of LDH was detected compared to mock-infected controls. The cytotoxic effect of the bacteria was time- and concentration-dependent.

To find out which cells were affected by the cytotoxic effect of $P$. multocida, we performed an analysis by confocal immunofluorescence microscopy. Bovine well-differentiated epithelial cells were infected by $P$. multocida 1701 strain. The filters were fixed at 4, 12, and $24 \mathrm{hpi}$ and subjected to immunofluorescence staining. As shown in Figure 3A, the tubulin positive area of infected samples was reduced. The decreased level of red fluorescence was quantified and found to be significant (Figure 3B). This finding indicated that P. multocida infection resulted in the loss of ciliated cells. The decrease in the cilia staining was dependent on the number of bacteria applied and the inoculation time. In the sample with the highest bacterial load and longer initial infection time, only $30 \%$ of the cilia were visible $24 \mathrm{hpi}$ and this difference is statistically significant compared with uninfected controls ( $\mathrm{p}$-value $<0.01$ ) as well as the samples infected for $1 \mathrm{~h}$ with $100 \mathrm{CFU} /$ filter (p-value $<0.05)$.

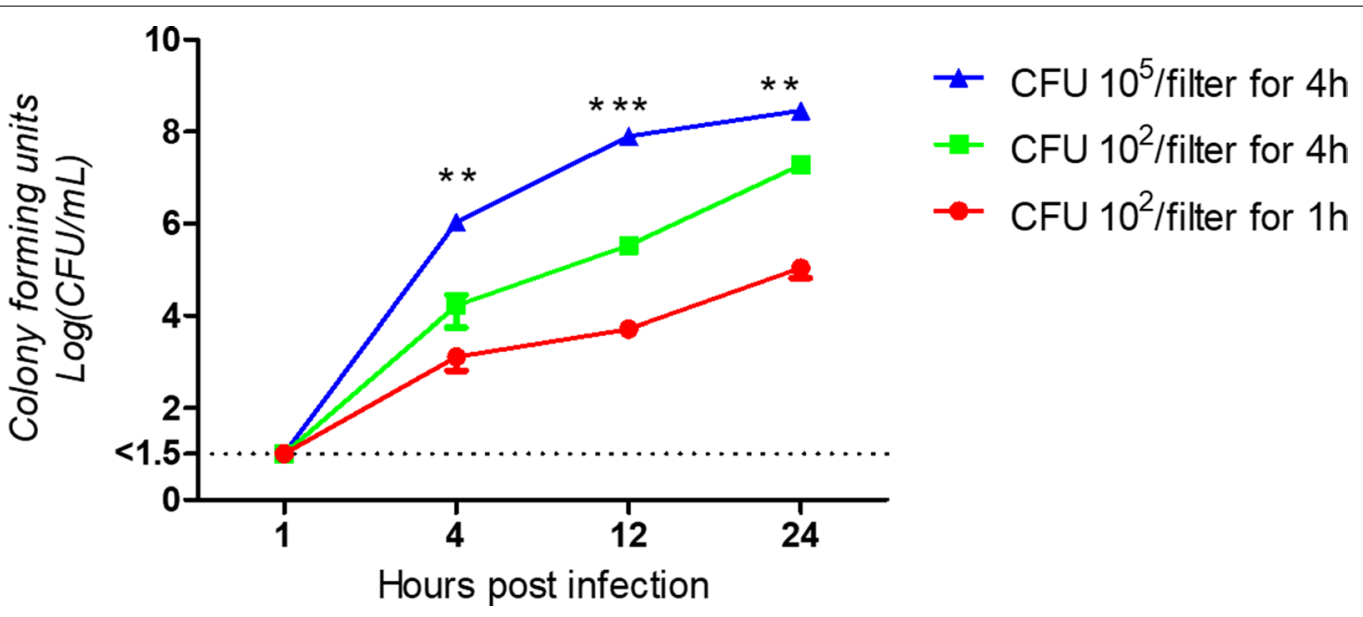

Figure 1 Growth kinetics of $P$. multocida in well-differentiated bovine airway epithelial cell cultures. Filter-grown well-differentiated bovine bronchial epithelial cells were infected with P. multocida by inoculation with $10^{2}$ or $10^{5} \mathrm{CFU}$ for $1 \mathrm{~h}$ or $4 \mathrm{~h}$. Supernatants were harvested at 4,12 and $24 \mathrm{hpi}$ and used to determine the growth kinetics. The significance of the differences between the values in each group is indicated with asterisks by comparing the CFU titer vertically. Results represent the mean values of CFU \pm SEM determined from three independent experiments with duplicated samples. ${ }^{* *} \mathrm{P}<0.001,{ }^{* *} \mathrm{P}<0.01$ and ${ }^{*} \mathrm{P}<0.05$. 

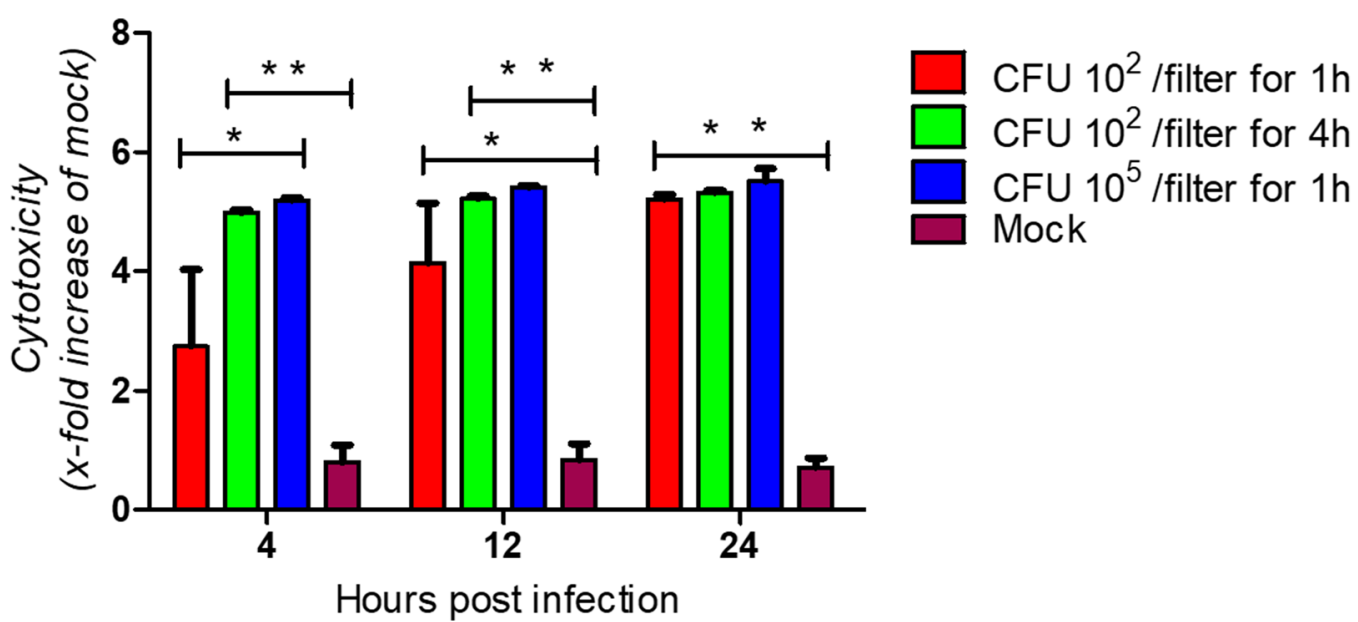
infected by P. multocida at the indicated inoculation conditions $\left(10^{2}\right.$ or $10^{5} \mathrm{CFU}, 1 \mathrm{~h}$ or $4 \mathrm{~h}$ ). At the times indicated, the amount of LDH released into the apical compartment was determined.

\section{Maintenance of the barrier function}

Next, we analyzed whether the loss of ciliated cells affects the barrier function of the epithelial cell layer. For this purpose, the transepithelial electrical resistance (TEER) was determined. As shown in Figure 4A, over a period of $24 \mathrm{hpi}$, none of the three inoculation scenarios resulted in a significant decrease. To confirm this result, a second assay was applied, which was based on the paracellular diffusion of dextran. As shown in Figure 4B, the macromolecule applied to the apical compartment was unable to reach the basolateral compartment, irrespective of the presence or absence of bacteria. Cells infected by $P$. multocida were found to have the same electrical resistance as mock-infected cells. By contrast, when the tight junctions were opened by treatment with EDTA, dextran was readily detected on the basolateral side of the cells.

To understand why the epithelial cells were able to maintain the barrier function despite a dramatic loss of ciliated cells, we analyzed vertical sections of confocal fluorescence micrographs. In Figure 5A, the staining of nuclei by DAPI, shows the picture that is characteristic for an intact epithelial layer. However, clear differences were observed between infected and mock-infected samples, with the most striking differences at $24 \mathrm{hpi}$, where very few ciliated cells were visible. The other difference observed was the considerable reduction in cell layer thickness, which was statistically significant and dependent on the length of the infection period. A reduction up to $30 \%$ was observed in infected samples after $24 \mathrm{hpi}$. This result suggests that the epithelial cells react upon the loss of ciliated cells by a rearrangement that results in a thinner cell layer but allows to maintain the barrier function.

\section{Importance of the bacterial neuraminidase for infection}

Finally, we were interested to know whether the ALIbased infection model for P. multocida can be used to analyze potential virulence factors. For this purpose, we chose the neuraminidase of $P$. multocida, an enzyme, which is reported to support bacterial growth by releasing sialic acid from the apical surface of the airway epithelial cells to be used as a carbon source for the bacterial metabolism. To prevent this action, we applied two inhibition conditions: on one hand, addition of 2-deoxy-2,3-didehydro- $\mathrm{N}$-acetylneuraminic acid (DANA, a neuraminidase inhibitor reagent) [39, 40] to directly prevent the enzyme activity and on the other hand, an indirect way to set the enzyme out of action by pretreating the cells with exogenous neuraminidase. In this way, sialic acids were released from the cell surface prior to infection and could not be used for bacterial growth. Therefore, the infection protocol was extended by including samples that either included the inhibitor DANA during the whole infection period or had been pretreated with neuraminidase from $C$. perfringens. For this purpose, we chose inoculation condition of $10^{2} \mathrm{CFU}, 1 \mathrm{~h}$. As reported above, infection of bovine ALI cultures by $P$. multocida, resulted in a loss of ciliated cells 24 hpi (Figure 6A). The cilia staining at this time point was reduced by more than $30 \%$ (red columns) and the difference was statistically significant 


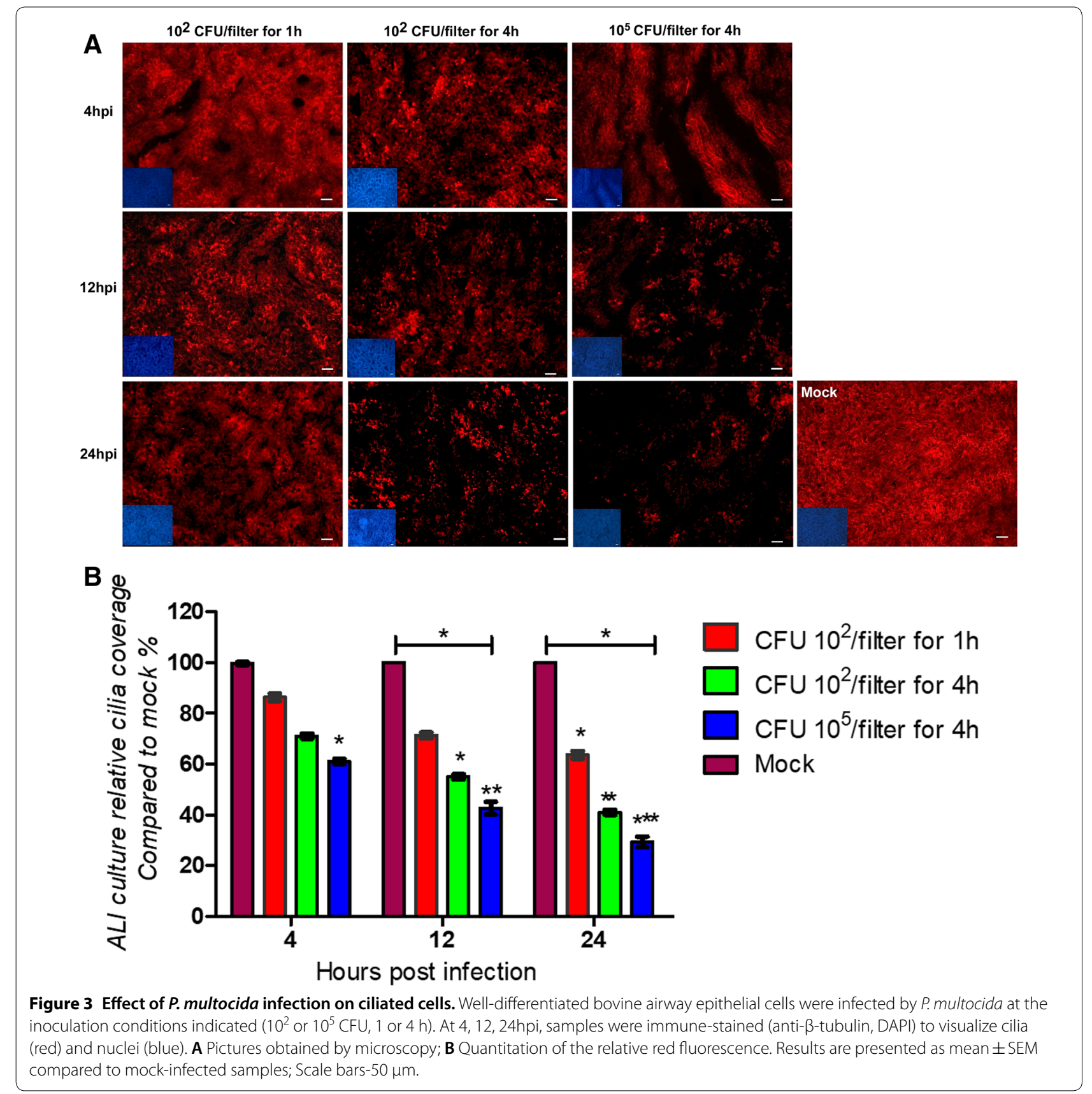

(Figure 6B). Both the treatment with DANA (green columns) and the pretreatment with neuraminidase (blue columns) prevented this effect. Their values were only slightly lower compared to the mock-infected samples (brown columns) and these differences were not statistically significant. This result illustrates that the neuraminidase of $P$. multocida contributes to the detrimental effect of this pathogen in ALI cultures. Therefore, this infection model is an interesting tool to analyze virulence factors of this pathogen.

\section{Discussion}

Though P. multocida is considered as one of the most prevalent commensals and opportunistic pathogens worldwide [7,8], little information is available about the bacteria-host interactions. We applied an ALI culture system of bovine airway epithelial cells to analyze the interactions of $P$. multocida with differentiated respiratory epithelial cells. We were able to show that the bacteria were capable to grow very efficiently under ALI conditions. The efficient microbial replication 
A
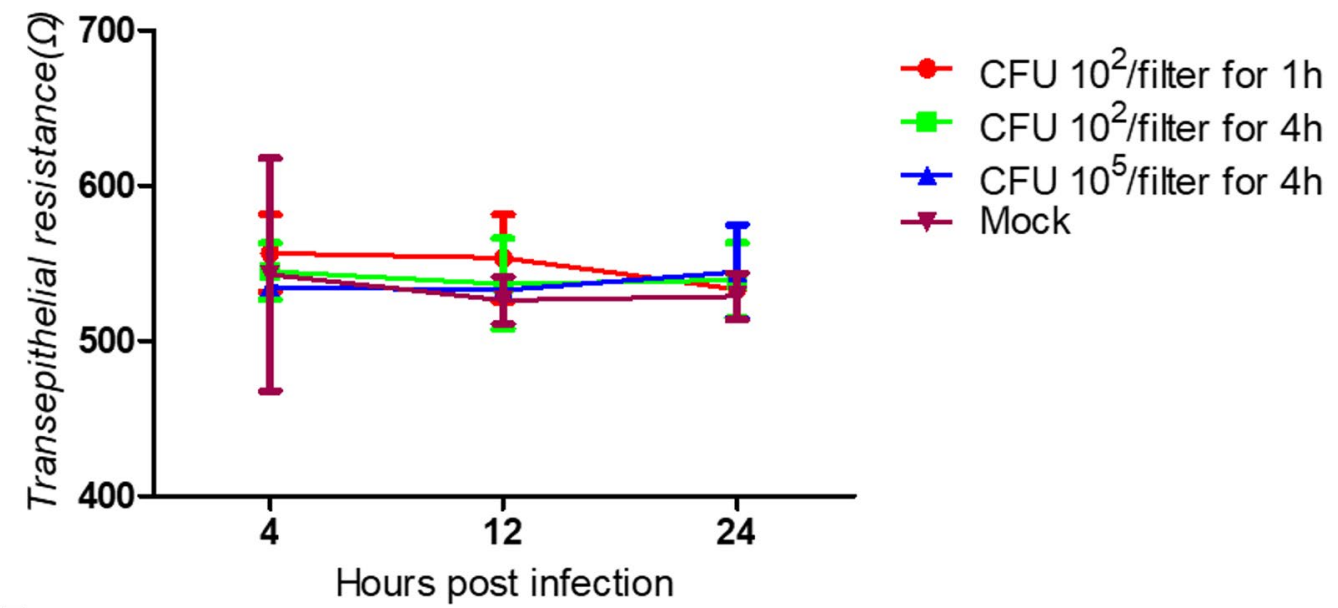

B

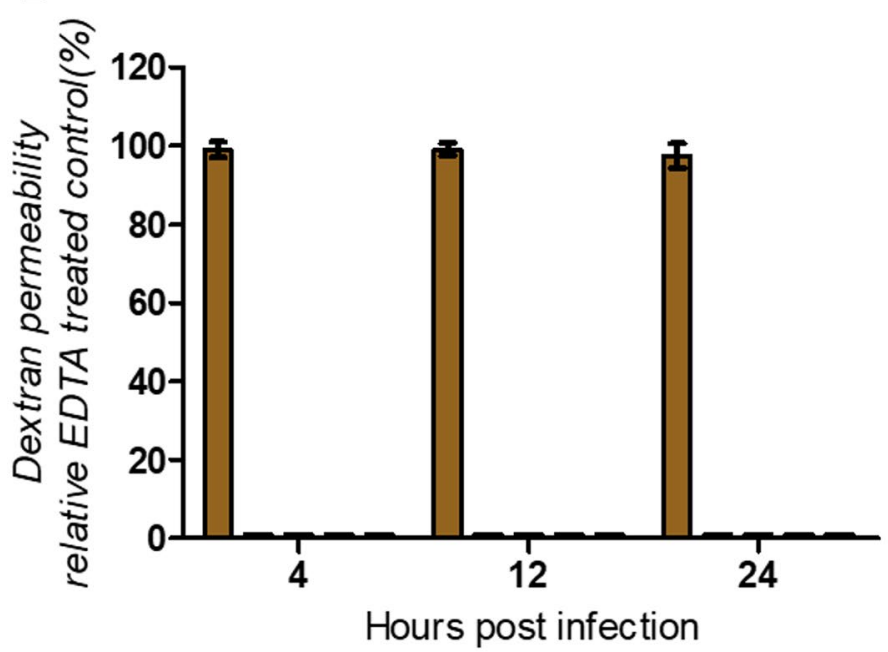

Figure 4 Barrier function of bovine well-differentiated airway epithelial cells after infection by $P$. multocida. Filter-grown ALI cultures of differentiated bovine airway epithelial cells were infected by P. multocida at the indicated inoculation conditions (10² or $10^{5}$ CFU; 1 or $4 \mathrm{~h}$ ). At the times indicated, samples were analyzed for the intactness of the barrier function $\mathbf{A}$ by determining the transepithelial electrical resistance (TEER) and $\mathbf{B}$ by determining the permeability for FITC-labeled dextran.

resulted in a toxic effect, which was evident not only by the release of $\mathrm{LDH}$, but also in a substantial reduction of the number of ciliated cells and cell layers. The loss of ciliated cells may be explained by bacteria-induced apoptosis [31]. This assumption is based on findings with ALI cultures infected by influenza viruses and Streptococcus suis $[27,31]$. This infection model is also characterized by a loss of ciliated cells and it has been shown that the infected ciliated cells undergo apoptosis. Another similarity of the viral and the bacterial infection model is that the loss of ciliated cells is not associated with a loss of the barrier function of the epithelial cell layer [27, 31, 41]. Neither ions nor macromolecules can pass via the paracellular route from the apical to the basolateral side of the cells. A substantial reorganization of the remaining cells is required to maintain the TEER and the impermeability for DEAEdextran. One possibility to compensate the loss of ciliated cells is that basal cells start to multiply and fill the gap. The full differentiation process, i.e. the acquisition of cilia may take more than two weeks. We hypothesize that the cells may adopt a polarized organization including tight junctions already early in the differentiation process and thus contribute to the barrier function. An alternative possibility is that only part of the ciliated cells are lost and others are undergoing a dedifferentiation process and thus contribute to the reorganization process required for maintaining the barrier 

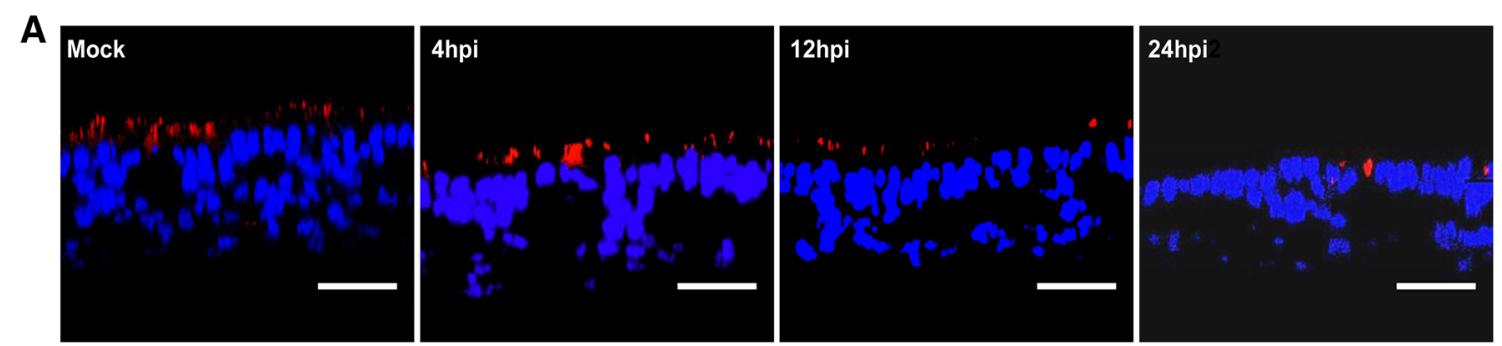

$\mathbf{B}$

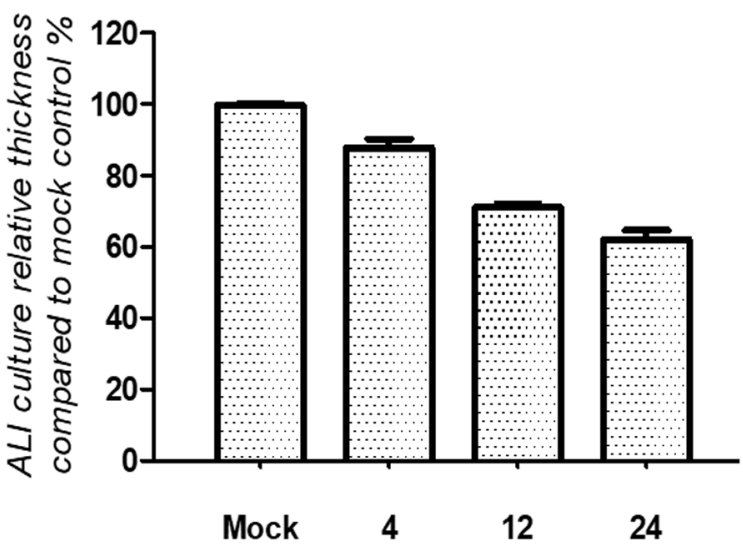

Hours post infection

Figure 5 Effect of infection by P. multocida on the thickness of the epithelial cell layer. Differentiated bovine airway epithelial cells were infected by P. multocida at the indicated inoculation conditions $\left(10^{2}\right.$ or $10^{5} \mathrm{CFU} ; 1$ or $4 \mathrm{~h}$ ) and immune-stained as described in Figure 3 . A Vertical sections of the immunostained samples; $\mathbf{B}$ relative thickness of the epithelial cell layer compared to mock infected samples. Scale bars, $50 \mu \mathrm{m}$.

function. Whatever possibility is true, our results show that not only the bacterial infection is efficient, but also the response of the epithelial cells is also efficient. The factors involved in the regeneration of the basal epithelial cells for maintaining barrier integrity remain to be further investigated.

Though the infected epithelial cell layer may maintain the barrier function, it takes some time until the compensation of ciliated cells is completed. In the transition phase, the area of infection lacks ciliated cells for some time and thus is not fully protected by the mucociliary clearance system. Therefore, these cells may be more susceptible to infection by other microorganisms; this assumption provides an explanation how P. multocida can facilitate co-infection and thus contribute to BRDC.

Under the conditions chosen for this study, the epithelial cells maintained the barrier function up to $24 \mathrm{hpi}$. When the bacteria were allowed to amplify for a longer time, a number of cells were lost which resulted in the decline of the TEER values indicating that the epithelium could not maintain its barrier function (not shown). This observation may raise the question why $P$. multocida usually is not pathogenic per se, but rather a commensal that becomes pathogenic only under special conditions. One reason for this may be that the ALI culture system has mucus and ciliary activity, but in contrast to the airways, the mucus is not transported out of the system and thus not removed from the epithelial cells. The clearance system of the host may keep the bacterial load at a low level and thus prevent the bacteria from becoming pathogenic. This explanation is supported by our finding that bacteria could be efficiently collected from the surface of the mucus-covered epithelial cells by washing with PBS. This result indicates that the binding of $P$. multocida is not very tight. In fact, after thorough washing only few bacteria were detected on the cell surface by immunostaining (not shown).

Our results show that the bovine ALI infection model can be used to analyze virulence factors of $P$. multocida. By applying the inhibitor DANA, we confirmed that the bacterial neuraminidase is crucial for efficient amplification. The function of this enzyme is thought to release sialic acid from cell surface macromolecules to be used as an energy source for the metabolism of P. multocida [42]. This view is supported by our second inhibitor scenario. When the cells were pretreated with an exogenous neuraminidase, the bacteria encountered desialylated cells and the enzyme of $P$. multocida had no substrate 


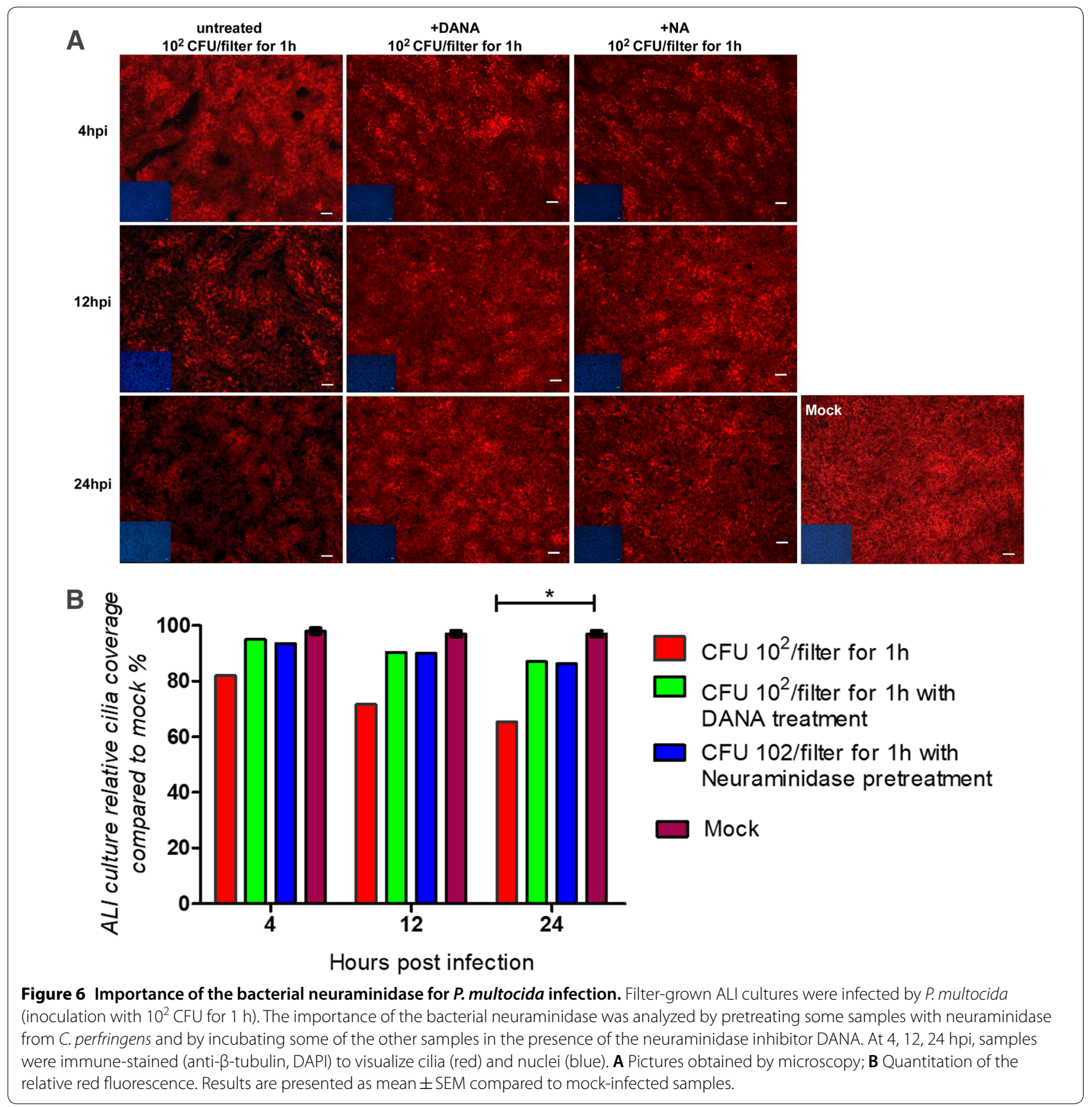

to release sialic acid and thus was unable to provide a substrate for the bacterial metabolism. While this manuscript was prepared for submission, a report was published in which ALI cultures of bovine airway epithelial cells were used to analyze the infection by a related pathogen, Mannheimia haemolytica. These authors found that the barrier function was maintained though $M$. haemolytica preferentially affected non-ciliated cells. Different from our study, in those experiments, infection was initiated with a high bacterial load. Under these conditions, $M$. haemolytica serotype A1, but not A2, became invasive and crossed the epithelial barrier by transcytosis [43]. This finding underscores that ALI cultures are a valuable tool that can provide results that cannot be obtained with immortalized cells.

Taken together, we have established an in vitro infection model that enables to analyze the interaction of $P$. multocida with its target cells in the respiratory tract. In 
this way, we could characterize the detrimental effect of the bacteria and the response of the airway cells. The ALI infection model was also used to characterize the importance of the bacterial neuraminidase and should be helpful in the future also for analyzing other virulence factors of P. multocida.

\section{Acknowledgements}

This work was performed by AS in partial fulfillment of the requirements for doctoral degrees from University of Veterinary Medicine Hannover. We are grateful to China Scholarship Council for providing fellowship for AS.

\section{Authors' contributions}

GH and JM designed the experiments; AS performed the experiments; AS, JT and GH analyzed the data; AS, JT, YF, JM and GH wrote or helped to draft the paper. All authors read and approved the final manuscript.

\section{Funding}

Open Access funding enabled and organized by Projekt DEAL.. This research was funded by German Research Foundation (DFG) grants to GH (HE 1168/171) and JM (ME 1833/1-1).

\section{Availability of data and materials}

The dataset supporting the conclusions of this article is included within the article (and its additional file(s)).

\section{Ethics approval and consent to participate}

All lungs from calves used for these experiments were obtained from local slaughter company in Germany. Study design, including all measures were approved by a local, independent committee on ethics (Commission for ethical estimation of animal research studies of the Lower Saxonian State Office for Consumer Protection and Food Safety (approval number 33.9-42502-0509A627) and were in accordance with the requirements of the national animal welfare law. Compliance with animal welfare law and ethics were regularly controlled by the local authorities. All experiments were approved by and performed at the University of Veterinary Medicine Hannover (No. 20190415).

\section{Consent for publication}

Not applicable.

\section{Competing interests}

The authors declare that they have no competing interests.

\section{Author details}

1 Institute of Virology, University of Veterinary Medicine Hannover, Foundation, 30559 Hannover, Germany. ${ }^{2}$ Institute of Microbiology, University of Veterinary Medicine Hannover, Foundation, 30559 Hannover, Germany. ${ }^{3}$ State Key Laboratory of Veterinary Etiological Biology, Lanzhou Veterinary Research Institute, Chinese Academy of Agricultural Sciences, Lanzhou 730046, China. ${ }^{4}$ College of Life Science, Institute of Life Science and Green Development, Hebei University, Baoding 071002, China.

Received: 8 July 2020 Accepted: 22 October 2020

Published online: 23 November 2020

\section{References}

1. Wilson BA, Ho M (2013) Pasteurella multocida: From zoonosis to cellular microbiology. Clin Microbiol Rev 26(3):631-655. https://doi.org/10.1128/ CMR.00024-13

2. Snowder GD, Van Vleck LD, Cundiff LV, Bennett GL (2006) Bovine respiratory disease in feedlot cattle: environmental, genetic, and economic factors. J Anim Sci 84(8):1999-2008. https://doi.org/10.2527/jas.2006-046

3. Caswell JL (2014) Failure of respiratory defenses in the pathogenesis of bacterial pneumonia of cattle. Vet Pathol 51(2):393-409. https://doi. org/10.1177/0300985813502821
4. Srikumaran S, Kelling CL, Ambagala A (2007) Immune evasion by pathogens of bovine respiratory disease complex. Anim Health Res Rev 8(2):215-229. https://doi.org/10.1017/s1466252307001326

5. McDaneld TG, Kuehn LA, Keele JW (2018) Evaluating the microbiome of two sampling locations in the nasal cavity of cattle with bovine respiratory disease complex (brdc). J Anim Sci 96(4):1281-1287. https://doi. org/10.1093/jas/sky032

6. Gershwin LJ, Van Eenennaam AL, Anderson ML, McEligot HA, Shao MX, Toaff-Rosenstein R, Taylor JF, Neibergs HL, Womack J, Bovine Respiratory Disease Complex Coordinated Agricultural Project Research T (2015) Single pathogen challenge with agents of the bovine respiratory disease complex. PLoS One 10(11):e0142479. https://doi.org/10.1371/journ al.pone. 0142479

7. Harper M, Boyce JD, Adler B (2006) Pasteurella multocida pathogenesis: 125 years after pasteur. FEMS Microbiol Lett 265(1):1-10. https://doi.org/1 0.1111/j.1574-6968.2006.00442.x

8. Dabo SM, Taylor JD, Confer AW (2007) Pasteurella multocida and bovine respiratory disease. Anim Health Res Rev 8(2):129-150. https://doi. org/10.1017/S1466252307001399

9. Boukahil I, Czuprynski CJ (2018) Mutual antagonism between mannheimia haemolytica and pasteurella multocida when forming a biofilm on bovine bronchial epithelial cells in vitro. Vet Microbiol 216:218-222. https ://doi.org/10.1016/j.vetmic.2018.02.015

10. Thomas AC, Bailey M, Lee MRF, Mead A, Morales-Aza B, Reynolds R, Vipond B, Finn A, Eisler MC (2019) Insights into pasteurellaceae carriage dynamics in the nasal passages of healthy beef calves. Sci Rep 9(1):11943. https://doi.org/10.1038/s41598-019-48007-5

11. McMullen C, Alexander TW, Leguillette R, Workentine M, Timsit E (2020) Topography of the respiratory tract bacterial microbiota in cattle. Microbiome 8(1):91. https://doi.org/10.1186/s40168-020-00869-y

12. Boyce JD, Adler $B$ (2000) The capsule is a virulence determinant in the pathogenesis of pasteurella multocida m 1404 (b:2). Infect Immun 68(6):3463-3468. https://doi.org/10.1128/iai.68.6.3463-3468.2000

13. Khamesipour F, Momtaz H, Azhdary Mamoreh M (2014) Occurrence of virulence factors and antimicrobial resistance in pasteurella multocida strains isolated from slaughter cattle in iran. Front Microbiol 5:536. https ://doi.org/10.3389/fmicb.2014.00536

14. White DJ, Jolley WL, Purdy CW, Straus DC (1995) Extracellular neuraminidase production by a pasteurella multocida a:3 strain associated with bovine pneumonia. Infect Immun 63(5):1703-1709. https://doi. org/10.1128/IAl.63.5.1703-1709.1995

15. Straus DC, Cooley JD, Purdy CW (1996) In vivo production of neuraminidase by pasteurella multocida a:3 in goats after transthoracic challenge. Curr Microbiol 33(4):266-269. https://doi.org/10.1007/s002849900111

16. Mizan S, Henk A, Stallings A, Maier M, Lee MD (2000) Cloning and characterization of sialidases with 2-6' and 2-3' sialyl lactose specificity from pasteurella multocida. J Bacteriol 182(24):6874-6883. https://doi. org/10.1128/jb.182.24.6874-6883.2000

17. Harper M, Cox AD, Adler B, Boyce JD (2011) Pasteurella multocida lipopolysaccharide: The long and the short of it. Vet Microbiol 153(1-2):109-115. https://doi.org/10.1016/j.vetmic.2011.05.022

18. Straus DC, Jolley WL, Purdy CW (1996) Characterization of neuraminidases produced by various serotypes of pasteurella multocida. Infect Immun 64(4):1446-1449. https://doi.org/10.1128/lai.64.4.1446-1449.1996

19. Kahya HF, Andrew PW, Yesilkaya H (2017) Deacetylation of sialic acid by esterases potentiates pneumococcal neuraminidase activity for mucin utilization, colonization and virulence. PLoS Pathog 13(3):e1006263. https ://doi.org/10.1371/journal.ppat.1006263

20. Vimr ER, Kalivoda KA, Deszo EL, Steenbergen SM (2004) Diversity of microbial sialic acid metabolism. Microbiol Mol Biol Rev 68(1):132-153. https://doi.org/10.1128/mmbr.68.1.132-153.2004

21. Owen CD, Tailford LE, Monaco S, Suligoj T, Vaux L, Lallement R, Khedri Z, Yu H, Lecointe K, Walshaw J, Tribolo S, Horrex M, Bell A, Chen X, Taylor GL, Varki A, Angulo J, Juge N (2017) Unravelling the specificity and mechanism of sialic acid recognition by the gut symbiont ruminococcus gnavus. Nat Commun 8(1):2196. https://doi.org/10.1038/s41467-017-02109-8

22. Bustamante-Marin XM, Ostrowski LE (2017) Cilia and mucociliary clearance. Cold Spring Harb Perspect Biol 9(4):a028241. https://doi. org/10.1101/cshperspect.a028241 
23. Thornton DJ, Rousseau K, McGuckin MA (2008) Structure and function of the polymeric mucins in airways mucus. Annu Rev Physiol 70(1):459-486. https://doi.org/10.1146/annurev.physiol.70.113006.100702

24. Ganesan S, Comstock AT, Sajjan US (2013) Barrier function of airway tract epithelium. Tissue Barriers 1(4):e24997. https://doi.org/10.4161/tisb.24997

25. Linden SK, Sutton P, Karlsson NG, Korolik V, McGuckin MA (2008) Mucins in the mucosal barrier to infection. Mucosal Immunol 1(3):183-197. https ://doi.org/10.1038/mi.2008.5

26. Tilley AE, Walters MS, Shaykhiev R, Crystal RG (2015) Cilia dysfunction in lung disease. Annu Rev Physiol 77:379-406. https://doi.org/10.1146/ annurev-physiol-021014-071931

27. Wu NH, Yang W, Beineke A, Dijkman R, Matrosovich M, Baumgartner W, Thiel V, Valentin-Weigand P, Meng F, Herrler G (2016) The differentiated airway epithelium infected by influenza viruses maintains the barrier function despite a dramatic loss of ciliated cells. Sci Rep 6:39668. https:// doi.org/10.1038/srep39668

28. Lam E, Ramke M, Groos S, Warnecke G, Heim A (2011) A differentiated porcine bronchial epithelial cell culture model for studying human adenovirus tropism and virulence. J Virol Methods 178(1-2):117-123. https://doi.org/10.1016/j.jviromet.2011.08.025

29. Liu X, Luo M, Zhang L, Ding W, Yan Z, Engelhardt JF (2007) Bioelectric properties of chloride channels in human, pig, ferret, and mouse airway epithelia. Am J Respir Cell Mol Biol 36(3):313-323. https://doi. org/10.1165/rcmb.2006-02860C

30. Kirchhoff J, Uhlenbruck S, Goris K, Keil GM, Herrler G (2014) Three viruses of the bovine respiratory disease complex apply different strategies to initiate infection. Vet Res 45(1):20. https://doi.org/10.1186/1297-9716-45-20

31. Meng F, Wu NH, Seitz M, Herrler G, Valentin-Weigand P (2016) Efficient suilysin-mediated invasion and apoptosis in porcine respiratory epithelial cells after streptococcal infection under air-liquid interface conditions. Sci Rep 6:26748. https://doi.org/10.1038/srep26748

32. Tam A, Wadsworth S, Dorscheid D, Man SF, Sin DD (2011) The airway epithelium: more than just a structural barrier. Ther Adv Respir Dis 5(4):255-273. https://doi.org/10.1177/1753465810396539

33. Müller S (2019) Precision-cut lung slices (pcls) as an ex vivo model to study host-pathogen interaction of pasteurella multocida in differentiated airway epithelium. Doctoral Thesis, Tierärztliche Hochschule, Hannover,

34. Ewers C, Lubke-Becker A, Bethe A, Kiebling S, Filter M, Wieler LH (2006) Virulence genotype of pasteurella multocida strains isolated from different hosts with various disease status. Vet Microbiol 114(3-4):304-317. https:// doi.org/10.1016/j.vetmic.2005.12.012
35. Ujvári B, Makrai L, Magyar T (2019) Virulence gene profiling and ompa sequence analysis of pasteurella multocida and their correlation with host species. Vet Microbiol 233:190-195. https://doi.org/10.1016/j.vetmi c.2019.05.005

36. Rajkhowa S (2015) Development of a novel multiplex pcr assay for rapid detection of virulence associated genes of pasteurella multocida from pigs. Lett Appl Microbiol 61(3):293-298. https://doi.org/10.1111/ lam.12453

37. Townsend KM, Boyce JD, Chung JY, Frost AJ, Adler B (2001) Genetic organization of pasteurella multocida cap loci and development of a multiplex capsular pcr typing system. J Clin Microbiol 39(3):924-929. https://doi.org/10.1128/JCM.39.3.924-929.2001

38. Jablonski PE, Jaworski M, Hovde CJJFml, (1996) A minimal medium for growth of pasteurella multocida. FEMS Microbiol Lett 140(2-3):165-169. https://doi.org/10.1111/j.1574-6968.1996.tb08331.x

39. Richter M, Schumann L, Walther E, Hoffmann A, Braun H, Grienke U, Rollinger JM, von Grafenstein S, Liedl KR, Kirchmair J, Wutzler P, Sauerbrei A, Schmidtke M (2015) Complementary assays helping to overcome challenges for identifying neuraminidase inhibitors. Future Virol 10(2):77-88. https://doi.org/10.2217/Fvl.14.97

40. Nishikawa T, Shimizu K, Tanaka T, Kuroda K, Takayama T, Yamamoto T, Hanada N, Hamada Y (2012) Bacterial neuraminidase rescues influenza virus replication from inhibition by a neuraminidase inhibitor. PLoS One 7(9):e45371. https://doi.org/10.1371/journal.pone.0045371

41. Fu Y, Durrwald R, Meng F, Tong J, Wu NH, Su A, Yin X, Haas L, Schmidtke M, Zell R, Krumbholz A, Herrler G (2019) Infection studies in pigs and porcine airway epithelial cells reveal an evolution of a(h1n1)pdm09 influenza a viruses toward lower virulence. J Infect Dis 219(10):1596-1604. https:// doi.org/10.1093/infdis/jiy719

42. Steenbergen SM, Lichtensteiger CA, Caughlan R, Garfinkle J, Fuller TE, Vimr ER (2005) Sialic acid metabolism and systemic pasteurellosis. Infect Immun 73(3):1284-1294. https://doi.org/10.1128/IAI.73.3.1284-1294.2005

43. Cozens D, Sutherland E, Lauder M, Taylor G, Berry CC, Davies RL (2019) Pathogenic mannheimia haemolytica invades differentiated bovine airway epithelial cells. Infect Immun 87:6. https://doi.org/10.1128/IAl.00078 $-19$

\section{Publisher's Note}

Springer Nature remains neutral with regard to jurisdictional claims in published maps and institutional affiliations.
Ready to submit your research? Choose BMC and benefit from:

- fast, convenient online submission

- thorough peer review by experienced researchers in your field

- rapid publication on acceptance

- support for research data, including large and complex data types

- gold Open Access which fosters wider collaboration and increased citations

- maximum visibility for your research: over $100 \mathrm{M}$ website views per year

At BMC, research is always in progress.

Learn more biomedcentral.com/submissions 